\title{
Test Anxiety and Associated Factors Among First-Year Health Science Students of University of Gondar, Northwest Ethiopia: A Cross-Sectional Study
}

Sisay Hanfesa

Tsinat Tilahun

Nigussie Dessie

Shegaye Shumet 1 iD

Endalamaw Salelew (iD)

Department of Psychiatry, College of Medicine and Health Sciences, University of Gondar, Gondar, Ethiopia
This article was published in the following Dove Press journal:

Advances in Medical Education and Practice

Background: The experience of extreme worry and self-doubt before taking a test can drastically hinder an individual's ability to perform well and may lead to miserable. Studies about test anxiety and associated factors among first-year health science students in Ethiopia are limited. Therefore, this study is meant to provide essential data for future interventions. Objective: To assess test anxiety and associated factors among first-year regular undergraduate health science students of the University of Gondar, northwest Ethiopia, 2019.

Methods: An institutional-based cross-sectional study with a stratified random sampling technique. Test anxiety was assessed using the Test Anxiety Questionnaire. Data were analyzed using Statistical Package for Social Science (SPSS) version 20. Bivariate and multivariate logistic regression analysis was performed. A $P$-value of less than 0.05 was considered statistically significant in the multivariate analysis, and the strength of association was measured using adjusted odds ratio at a $95 \%$ confidence interval.

Results: In this study, the prevalence of test anxiety was $54.7 \%(95 \% \mathrm{CI}=49.40-60.20)$. The result revealed that fathers' education of grade 9-12 (AOR $=0.31,95 \% \mathrm{CI}=0.14-0.69)$, mothers' education of grade $9-12(\mathrm{AOR}=2.43,95 \% \mathrm{CI}=1.07-5.47)$, psychological distress $(\mathrm{AOR}=8.37,95 \% \mathrm{CI}=4.29-16.39)$, the field of studies; midwifery (AOR=3.56, 95\% $\mathrm{CI}=1.07-11.76)$, and medicine $(\mathrm{AOR}=6.79,95 \% \mathrm{CI}=1.64-28.22)$ were significantly associated with test anxiety at a $P$-value $<0.05$.

Conclusion: The study found that test anxiety is a major problem of first-year undergraduate health science students. Mothers' education of grades 9-12, psychological distress, midwifery, and medical field of studies were risk factors of test anxiety, whereas fathers' education of grade 9-12 was protective for test anxiety. This showed that an increment in the education of father and mother has a controversial effect on test anxiety. It can be reduced by providing suitable trainings for first-year health science students in dealing with factors causing test anxiety.

Keywords: test anxiety, undergraduate first-year, health science students, test anxiety questionnaire, Ethiopia

\section{Introduction}

Anxiety is considered when the worry is excessive or disproportionate to the underlying threat, involves the expectation of future threat, and it is often considered as a disease when associated with personal distress, abnormal behavior,
Correspondence: Endalamaw Salelew Department of Psychiatry, College of Medicine and Health Sciences,

University of Gondar, P.O. Box: 196,

Gondar, Ethiopia

Tel +2519100047II

Email esalelew@gmail.com
Advances in Medical Education and Practice 2020:1 I 817-824 
impaired concentration, or avoidance. ${ }^{1}$ Test-anxiety is a physiological condition in which people experience extreme stress, anxiety, and discomfort during or before taking a test. ${ }^{2}$ In a test-oriented community, students' lifestyles are considerably affected by their test performance. Possibly due to the pressure to perform well, among other factors, students often experience heightened stress and anxiety during tests; thus, test anxiety is one of the factors which are responsible for students' underachievement and low performance. ${ }^{3}$ The major factors causing examination anxiety were excessive course load, fear of failure during exam, and studying all night before exams. ${ }^{4}$ Studies revealed that undergraduate students reported significantly higher levels of test anxiety compared to graduate students. ${ }^{5}$ Test anxiety is increasing in college students at a concerning rate, as their responsibilities to get anoptimal result increase, with family and personal pressure pushing them to the edge, and is a common problem among first year University students. ${ }^{6}$

Approximately $25-40 \%$ of US students suffer from test anxiety. ${ }^{7}$ Many college students experience academicrelated anxiety during their collegiate careers. Previous research suggests $10-35 \%$ of college students experience functionally impairing levels of test anxiety, ${ }^{8}$ which are negatively associated with the academic performance. ${ }^{9,10}$

Test anxiety can drastically hinder an individual's ability to perform well, and negatively affects their social, emotional, and behavioral development and feelings about themselves and school. ${ }^{2,3}$ In the higher level, test anxiety results in lower test scores, and there is an increased relation of test anxiety, and test performance, although adverse exam stress can also result in metabolic syndrome, hypertension, and infertility. ${ }^{9}$ Students suffer from low self-esteem, constantly looking at the time clock, pencil tapping, and giving worrying gestures. ${ }^{9,11}$ Previous works revealed that the prevalence of test anxiety ranged from $13.3-71 \%$ among undergraduate students, ${ }^{12-}$ 23 and factors associated with test anxiety were; sex, excessive course load, low self-efficacy, negative family environment, and over protection, lack of self-confidence, no educated at home, maladaptive perfectionism, and lack of time for preparation. ${ }^{5,-24-29}$

Despite the severity of the problems, studies on the prevalence and determinants of test anxiety among firstyear undergraduate health science students in Ethiopia are limited. For the academic staff, knowing about test anxiety and associated factors will help them to intervene in the future. Therefore, this study will provide the necessary information about test anxiety and associated factors among the study participants.

\section{Methods and Materials \\ Study Setting}

An institutional-based cross-sectional study was carried out on first-year regular undergraduate health science students at the University of Gondar, College of Medicine and Health Sciences from May and June 2019. It is one of the oldest Universities in the country, established in 1954, located in Gondar town northwest, Ethiopia. It has both postgraduate and undergraduate fields of study. The health science college currently offers about 12 undergraduate and 44 postgraduate degree programs. It has a total of 5,994 undergraduate students, and 813 first-year regular undergraduates, with 352 female and 461 male students.

\section{Population}

All first-year undergraduate health science students at the University of Gondar College of Medicine and Health Sciences were the source population. Those students included in the sample during the study period and from whom information was collected were the study participants after excluding those who were ill (unable to attend the class), or postbasic first-year health science students at the movement.

\section{Sample Size Determination and Technique}

The sample size was determined using a single population proportion formula by assuming the prevalence of test anxiety was $71 \%$, taken from a study conducted in Addis Ababa University among Technology students, ${ }^{23}$ with $95 \%$ of confidence level, and a 5\% margin of error; by adding a $10 \%$ non-response rate, a total sample of 349 was obtained. A stratified random sampling technique was used to recruit participants. First, proportional allocation of the study participants based on the number of students in a class was done, and the sampling interval was calculated by dividing the number of students in a class with the proportionally allocated number, which is equivalent with the total number of first year students divided by the sample $(813 / 349 \approx 2)$. Then, the first participant was selected by lottery method. Therefore, at every two regular interval, participants were invited to participate in the study.

\section{Measurement}

The questionnaire had six sections. The first section consists of the sociodemographic characteristics of the study 
participants. The second, test anxiety, was measured using the Test Anxiety Questionnaire (TAQ). The tool has 10items, and each item is scored $1-5$ according to specific criteria; "How often each statement describes them?" which is rated as 1 "never", 2 "rarely", 3 "half-time", 4 "often", and 5 "always". The sum up scores ranges from 10-50. A score of 10-19 indicates do not suffer from test anxiety, 20-35 indicates a moderate level of test anxiety, and over 35 indicates severe test anxiety. ${ }^{30}$ Third, social support: The Oslo 3-items social support questionnaire was used to assess social support. The scores range from 3-14, and scores of 3-8 show poor social support, 9-11 shows moderate social support, and 12-14 shows strong social support. ${ }^{31}$ Fourth, self-esteem: was measured using the 10-item scale of Rosenberg's self-esteem. The scale measures global self-worth by measuring both positive and negative feelings about the self. The scale consists of four points of Likert scale (" 0 " strongly disagree, "1" disagree, " 2 " agree, and " 3 " strongly agree). The scores range from 0-30. Scores from 0-15 shows low self-esteem, 15-25 shows normal self-esteem, and 25-30 shows high selfesteem. Items $2,5,6,8$, and 9 are reverse scored. ${ }^{32}$ Fifth, psychological distress: The Kessler Psychological Distress Scale is a 10 -item scale. The scores range from 10-50. Scores from 10-19 show wellness, 20-24 shows mild disorder, 25-29 shows a moderate disorder, and $30-50$ shows a severe disorder. ${ }^{33}$ Sixth, academic related: variables were assessed with a semi-structured questionnaire developed by the investigators after reviewing different literature.

\section{Data Collection and Analysis}

Data were collected using a self-administered English version of the questionnaire by trained psychiatric nurses. The collected data were checked for completeness and consistency, and pre-coded, entered into EPI info version 7.0, and exported to SPSS version 20 for further analysis. In a binary logistic regression analysis; variables found to have a $P$-value of less than 0.25 were candidates for multivariable logistic regression analysis. Variables $P$-value $<0.05$ was considered as statistically significant in the multivariate logistic regression analysis. The strength of association was explained with an Odds ratio at $95 \%$ confidence interval. The final compiled results were presented in the form of text, tables, pie charts, and graphs. The Test Anxiety Questionnaires' reliability was checked in this research with Cronbach's alpha $(\alpha=0.874)$.

\section{Ethical Considerations}

Ethical approval was obtained from the Institutional Review Board (IRB) of College of Medicine and Health Science (CMHS) of the University of Gondar (UoG) with the approval number of UoG-CMHS-187/19 and administered to the study subjects before the data collection. The participants were informed that the participation was voluntary and received informed written consent from study participants. Confidentiality was maintained by omitting personal identifiers. A letter of permission was obtained from the College of medicine and Health Sciences University of Gondar.

\section{Results \\ Socio-Demographic Characteristics}

A total of 349 participants were invited, and there was a response rate of $92.3 \%$. Few participants $(27,7.7 \%$ ) agreed to participate but failed to complete, so were not included. Around three-fifths $(190,59.0 \%)$, of the participants were males. The majority of the participants (236, $73.3 \%$ ) were below the age of $21,301(93.5 \%)$ were single, and $236(73.3 \%)$ were orthodox by religion, 217 (67.4\%) of the participants resided in urban areas. Some of the participants $(136,42.2 \%$, and $99,30.7 \%$ ) had father's and mother's education certificate and above (Table 1).

\section{Magnitude of Self-Esteem and Social Support}

Of the participants, 86 (26.7\%), 214 (66.5\%), and $22(6.8 \%)$ had low level, normal level, and high levels of self-esteem, respectively. More than half of the participants $(174,54.0 \%)$ had poor social support, 137 (42.5\%) had moderate social support, and 11 (3.4\%) had strong social support.

\section{Psychological Distress}

Regarding psychological distress, 163 (50.6\%) participants had normal, 59 (18.3\%) participants had mild psychological distress, 47 (14.6\%) participants had moderate psychological distress, and 53 (16.5\%) participants had severe psychological distress.

\section{Magnitude of Test Anxiety}

The magnitude of test anxiety defined by TAQ with a total cutoff point of 20 and above was $54.7 \%$ with a $95 \%$ CI of 49.40-60.20. In the other three categories, 146 (45.3\%) participants were found to not suffer from test anxiety, 155 (48.1\%) participants had a moderate level of test anxiety, 
Table I Sociodemographic Profiles of the Study Participants $(n=322)$

\begin{tabular}{|c|c|c|c|}
\hline Variables & $\begin{array}{l}\text { Variable } \\
\text { Categories }\end{array}$ & Frequency & Percentage \\
\hline Age & $\begin{array}{l}<21(18-20) \\
\geq 21\end{array}$ & $\begin{array}{l}236 \\
86\end{array}$ & $\begin{array}{l}73.3 \\
26.7\end{array}$ \\
\hline Sex & $\begin{array}{l}\text { Male } \\
\text { Female }\end{array}$ & $\begin{array}{l}190 \\
132\end{array}$ & $\begin{array}{l}59.0 \\
41.0\end{array}$ \\
\hline Marital status & $\begin{array}{l}\text { Single } \\
\text { Married } \\
\text { Separated }\end{array}$ & $\begin{array}{l}301 \\
18 \\
3\end{array}$ & $\begin{array}{l}93.5 \\
5.6 \\
0.9\end{array}$ \\
\hline Religion & $\begin{array}{l}\text { Orthodox } \\
\text { Protestant } \\
\text { Muslim } \\
\text { Catholic/ } \\
\text { Adventist }\end{array}$ & $\begin{array}{l}236 \\
45 \\
36 \\
5\end{array}$ & $\begin{array}{l}73.3 \\
14.0 \\
11.2 \\
1.5\end{array}$ \\
\hline $\begin{array}{l}\text { Father's education } \\
\text { status }\end{array}$ & $\begin{array}{l}\text { Non-educated } \\
\text { Grade I-4 } \\
\text { Grade 5-8 } \\
\text { Grade 9-12 } \\
\text { Certificate and } \\
\text { above }\end{array}$ & $\begin{array}{l}42 \\
44 \\
48 \\
52 \\
136\end{array}$ & $\begin{array}{l}13.0 \\
13.7 \\
14.9 \\
16.1 \\
42.2\end{array}$ \\
\hline $\begin{array}{l}\text { Mothers' } \\
\text { education status }\end{array}$ & $\begin{array}{l}\text { Non-educated } \\
\text { Grade I-4 } \\
\text { Grade 5-8 } \\
\text { Grade 9-12 } \\
\text { Certificate and } \\
\text { above }\end{array}$ & $\begin{array}{l}77 \\
39 \\
46 \\
61 \\
99\end{array}$ & $\begin{array}{l}23.9 \\
12.1 \\
14.3 \\
18.9 \\
30.7\end{array}$ \\
\hline Family's residency & $\begin{array}{l}\text { Urban } \\
\text { Rural }\end{array}$ & $\begin{array}{l}217 \\
105\end{array}$ & $\begin{array}{l}67.4 \\
32.6\end{array}$ \\
\hline
\end{tabular}

and $21(6.5 \%)$ participants had severe test anxiety (Figure 1).

\section{Factors Associated with Test Anxiety}

In a bivariate logistic regression analysis; sex, age, field of study, father's education, mother's education, self-esteem, marital status, family residency, psychological distress, alcohol ever use, and Grade Point Average (GPA) were candidates for multivariate logistic regression analysis at a $P$-value $<0.25$. In the final model; father's education, mother's education, psychological distress, midwifery, and medicine department students were significantly associated with test anxiety at a $P$-value $<0.05$. In multivariate logistic regression analysis, those with fathers' educational status of grade 9-12 were $70 \%$ more likely to develop test anxiety as compared to fathers' educational status of certificate and above $(\mathrm{AOR}=0.31,95 \% \mathrm{CI}=0.14-0.69)$, those

\section{Magnitude of Test anxiety}

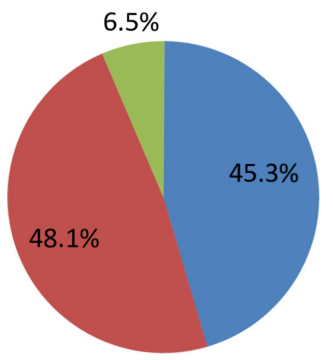

- low test anxiety

Moderate test anxiety

m severe test anxiety

Figure I The magnitude of test anxiety of among first-year undergraduate health science students of the University of Gondar, $2019(n=322)$.

with mother's educational status of grade 9-12 were 2.43times more likely to develop test anxiety as compared to mother's educational status of certificate and above $(\mathrm{AOR}=2.43,95 \% \mathrm{CI}=1.07-5.47)$, those with psychological distress were 8.37-times more likely to develop test anxiety as compared to having no psychological distress $(\mathrm{AOR}=8.37,95 \% \mathrm{CI}=4.29-16.39)$, those in the midwifery field of study were 3.56-times more likely to develop test anxiety, and those in the medicine field of study were 6.79times more likely to develop test anxiety compared to nursing department students $(\mathrm{AOR}=3.56,95 \% \mathrm{CI}=1.07-$ 11.76; and $\mathrm{AOR}=6.79,95 \% \mathrm{CI}=1.64-28.22$, respectively) (Table 2).

\section{Discussion}

In this study, the prevalence of test anxiety and its possible associated factors were assessed. The study revealed that significant proportions of first-year undergraduate health science students had test anxiety. The prevalence of test anxiety among study participants was found to be $54.7 \%$. This result is consistent with the magnitude of test anxiety reported in studies carried out in Ethiopia (52.3\%), ${ }^{12}$ Iran $(52.25 \%),{ }^{15}$ and Turkey (48\%). ${ }^{13}$ However, this finding is lower than those of studies carried out in India (83\%), ${ }^{34}$ and $(62.7 \%),{ }^{20}$ in two different settings, the United Arab Emirates (89.4\%), ${ }^{16}$ Malaysia (61.6\%), ${ }^{21}$ and Saudi Arabia $(65.3 \%) .^{22}$ The possible reasons for the discrepancies might be variations in study populations. For instance, this study was carried out on first-year health science students in 12 fields of study, while only medical students who had chances of an excessive course load were sampled in India ${ }^{20}$ and the United Arab Emirates. ${ }^{16}$ Furthermore, nursing students were dealt with in Malaysia and Saudi Arabia. Besides, differences in findings also relate to the tools used. For example, the Test Anxiety Inventory scale was put to use in the United Arab 
Table 2 Bivariate and Multivariate Logistic Regression Analysis of the Associated Factors ( $n=322)$

\begin{tabular}{|c|c|c|c|c|c|}
\hline \multirow[t]{2}{*}{ Variables } & \multirow[t]{2}{*}{ Category } & \multicolumn{2}{|c|}{ Test Anxiety } & \multirow[t]{2}{*}{ COR $(95 \% \mathrm{Cl})$} & \multirow[t]{2}{*}{ AOR $(95 \% \mathrm{Cl})$} \\
\hline & & Yes (\%) & No (\%) & & \\
\hline Age & $\begin{array}{l}\leq 20(18-20) \\
>20\end{array}$ & $\begin{array}{l}\text { II } 2(47.5) \\
34(39.5)\end{array}$ & $\begin{array}{l}124(52.5) \\
52(59.5)\end{array}$ & $\begin{array}{l}0.72(0.44-1.19) \\
1\end{array}$ & $\begin{array}{l}0.94(0.49-1.78) \\
I\end{array}$ \\
\hline Marital status & $\begin{array}{l}\text { Single } \\
\text { Married/separated }\end{array}$ & $\begin{array}{l}\text { I } 40(46.5) \\
6(28.6)\end{array}$ & $\begin{array}{l}161(53.5) \\
15(71.4)\end{array}$ & $\begin{array}{l}0.46(0.17-1.22) \\
\mathrm{I}\end{array}$ & $\begin{array}{l}0.35(0.11-1.06) \\
1\end{array}$ \\
\hline Fathers' education status & $\begin{array}{l}\text { Non-educated } \\
\text { Grade I-4 } \\
\text { Grade 5-8 } \\
\text { Grade 9-12 } \\
\text { Certificate and above }\end{array}$ & $\begin{array}{l}12(28.6) \\
17(38.6) \\
19(39.6) \\
33(63.5) \\
65(47.8)\end{array}$ & $\begin{array}{l}30(71.4) \\
27(61.4) \\
29(60.4) \\
19(36.5) \\
71(52.2)\end{array}$ & $\begin{array}{l}2.28(1.08-484) \\
1.45(0.73-2.91) \\
1.39(0.72-2.73) \\
0.53(0.27-1.07) \\
1\end{array}$ & $\begin{array}{l}1.24(0.5 \mathrm{I}-3.02) \\
0.82(0.36-1.88) \\
0.63(0.27-1.46) \\
0.31(0.14-0.69)^{* *} \\
1\end{array}$ \\
\hline Mothers' educational status & $\begin{array}{l}\text { Non-educated } \\
\text { Grade I-4 } \\
\text { Grade 5-8 } \\
\text { Grade 9-12 } \\
\text { Certificate and above }\end{array}$ & $\begin{array}{l}27(35.1) \\
14(35.9) \\
21(45.7) \\
30(49.7) \\
54(48.4)\end{array}$ & $\begin{array}{l}50(64.9) \\
25(64.1) \\
25(54.3) \\
31(50.8) \\
45(45.5)\end{array}$ & $\begin{array}{l}2.22(1.20-4.10) \\
2.14(0.99-4.60) \\
1.43(0.71-2.88) \\
1.24(0.65-2.35) \\
1\end{array}$ & $\begin{array}{l}1.08(0.32-3.63) \\
1.76(0.52-6.03) \\
2.13(0.74-6.06) \\
2.43\left(1.07-5.47^{*}\right) \\
I\end{array}$ \\
\hline Family residency & $\begin{array}{l}\text { Urban } \\
\text { Rural }\end{array}$ & $\begin{array}{l}105(54.5) \\
4 I(39.0)\end{array}$ & $\begin{array}{l}112(51.6) \\
64(61.0)\end{array}$ & $\begin{array}{l}\text { I } \\
0.68(0.43-1.11)\end{array}$ & $\begin{array}{l}\text { I } \\
0.93(0.42-2.15)\end{array}$ \\
\hline Self-esteem & $\begin{array}{l}\text { Low } \\
\text { Normal } \\
\text { High }\end{array}$ & $\begin{array}{l}25(29.1) \\
105(49.1) \\
16(72.7)\end{array}$ & $\begin{array}{l}61(70.9) \\
109(50.9) \\
6(27.3)\end{array}$ & $\begin{array}{l}6.5 \mathrm{I}(2.28-8.55) \\
2.77(1.04-7.35) \\
\mathrm{I}\end{array}$ & $\begin{array}{l}2.37(0.70-8.03) \\
2.04(0.69-6.02) \\
\text { । }\end{array}$ \\
\hline Psychological distress & $\begin{array}{l}\text { No } \\
\text { Yes }\end{array}$ & $\begin{array}{l}130(58.6) \\
16(16.0)\end{array}$ & $\begin{array}{l}92(4 I .4) \\
84(84.0)\end{array}$ & $\begin{array}{l}\text { I } \\
0.14(0.07-0.25)\end{array}$ & $\begin{array}{l}\text { I } \\
8.37(4.29-16.39)^{* * *}\end{array}$ \\
\hline Field of study & $\begin{array}{l}\text { Nurse } \\
\text { Midwifery } \\
\text { Psychiatry } \\
\text { Physiotherapy } \\
\text { Public health } \\
\text { Laboratory } \\
\text { Medicine } \\
\text { Anesthesia } \\
\text { Health informatics } \\
\text { Optometry } \\
\text { Environmental } \\
\text { Pharmacy }\end{array}$ & $\begin{array}{l}\text { I5 (3I.9) } \\
14(53.8) \\
9(47.4) \\
8(44.4) \\
12(50) \\
6(24.0) \\
44(63.8) \\
7(38.9) \\
9(47.4) \\
6(42.9) \\
5(25.0) \\
11(47.8)\end{array}$ & $\begin{array}{l}32(68.1) \\
12(46.2) \\
10(52.6) \\
10(55.6) \\
12(50) \\
19(76.0) \\
25(36.2) \\
11(61.1) \\
10(52.6) \\
8(57.1) \\
15(75.0) \\
12(52.2)\end{array}$ & $\begin{array}{l}\text { I } \\
\text { I.95 (0.70-5.44) } \\
0.78(0.26-2.42) \\
\text { I.0I (0.30-3.44) } \\
\text { I.I5(0.33-3.95) } \\
0.92(0.29-2.88) \\
2.90(0.85-9.93) \\
0.52(0.20-1.35) \\
1.44(0.41-5.04) \\
1.02(0.30-3.44) \\
1.22(0.32-4.66) \\
2.75(0.75-10.11)\end{array}$ & $\begin{array}{l}\text { I } \\
3.56(1.07-1 \mathrm{I} .76)^{*} \\
\text { I.95 }(0.5 \mathrm{I}-7.42) \\
\mathrm{I} .59(0.37-6.83) \\
2.99(0.67-13.43) \\
\mathrm{I} .63(0.42-6.32) \\
6.79(\mathrm{I} .64,8.22)^{* *} \\
0.95(0.29-3.04) \\
2.0 \mathrm{I}(0.47-8.5 \mathrm{I}) \\
\mathrm{I} .29(0.32-5.27) \\
3.18(0.67-15.1 \mathrm{I}) \\
3.49(0.76-16.10)\end{array}$ \\
\hline Grade point average & $\begin{array}{l}<3.00 \\
3.00-3.50 \\
>3.50\end{array}$ & $\begin{array}{l}31(43.1) \\
50(38.8) \\
65(53.7)\end{array}$ & $\begin{array}{l}4 I(56.9) \\
79(6 I .2) \\
56(46.3)\end{array}$ & $\begin{array}{l}\text { I.54 (0.85-2.76) } \\
\text { I.83(I.II-3.03) } \\
\text { I }\end{array}$ & $\begin{array}{l}0.99(0.46-2.16) \\
1.56(0.81-2.99)\end{array}$ \\
\hline
\end{tabular}

Notes: $* P$-value $<0.05, * * P$-value $<0.01$, $* * * P$-value $<0.001$.

Abbreviation: NB, significance.

Emirates and Saudi Arabia, whereas the Visual Analog Scale was utilized in India. Moreover, research results might also vary due to the sociocultural differences of participants.

On the other hand, the prevalence of test anxiety is higher than that of a study conducted on medical students in Uganda (13.3\%), ${ }^{14}$ India (37\%), ${ }^{18}$ Malaysia (18.2\%), ${ }^{17}$ and another study carried out among pharmacy students in Malaysia (32.5\%). ${ }^{19}$ The possible reason for the difference might be the tools used. In Uganda, for instance, the Hamilton Anxiety Rating Scale was employed, while the Westside Text Anxiety Scale (WTAS) was utilized in Malaysia, and the Test Anxiety Questionnaire was used 
in the current study. As a matter of fact, sociocultural variations are also responsible for the differences in study results.

In this study, the finding showed that having a father educated from 9-12 grade is less likely to cause test anxiety as compared to having a father educated to certificate and above. On the contrary, having a mother educated to grade 9-12 grade is more likely to cause test anxiety on students than having a mother educated to certificate and above. This is inconsistent with previous studies conducted in King Saud university, which indicated that having a non-educational family status is a risk factor to develop test anxiety. ${ }^{11,15}$ This means that fathers educational status certificate and above are risk factors for test anxiety, whereas mothers educated certificate and above are protective for test anxiety. In the previous works, overprotection, family pressure, and negative home environment are risk factors for test anxiety. ${ }^{6,28}$

On the contrary, this is inconsistent with a study conducted in Iran, to determine level of test anxiety and contributing factors among freshman students, ${ }^{15}$ and needs further study. The other reason might be when the parents educational status is certifiable and above, the pressure that the students get from their fathers to work hard to be disliked, and getting from their mothers to work hard to be like them.

In this study, psychological distress was significantly associated with test anxiety. This is supported by previous works carried out on test anxiety and psychological distress. Therefore, use of effective psychological interventions for test anxiety, to reduce psychological distress, and to enhance academic motivations are required. ${ }^{17,19,22}$

In the current study, a medical field of study was significantly associated to develop more test anxiety than a nursing field of study. This is in line with previous studies which reported on test anxiety among medical students. ${ }^{14,18,34}$ This might be due to the students' perceptions about the department, the excessive course load, and the difference in the evaluation system. This study also indicates that the midwifery field of study had a higher risk to develop test anxiety than a nursing field of study. The reason may be due to the discomfort and frustration they face in the clinical attachments, in field of studies, and their big concern on their skill practices. This area needs further study.

\section{Limitations}

That the study used a standard tool to assess test anxiety and associated factors is, we feel, its strength. On the other hand, the study was conducted at a single institution, and a cross-sectional study design could not show the causeeffect relationships.

\section{Conclusion}

In this study, the prevalence of test anxiety among study participants was high and needs to address the underlying conditions that interfere with learning ability. The result revealed that mothers' education from grade 9-12, psychological distress, midwifery and medicine field of study were risk factors associated with test anxiety and fathers' educational status of grade 9-12 was a protective factor. This showed that an increment in the education of father and mother has a controversial effect on test anxiety. It can be reduced by providing suitable training for first-year health science students in dealing with factors causing test anxiety.

\section{Consent to Publish}

Not applicable.

\section{Abbreviations}

AOR, adjusted odd ratio; COR, crude odd ratio; SPSS, Statistical Package for Social Science; TAI, Test Anxiety Inventory; TAQ, Test Anxiety Questionnaire; WTAS, Westside Test Anxiety Scale.

\section{Data Sharing Statement}

The data and materials used in this study are available from the corresponding author.

\section{Ethics Approval and Consent}

Ethical approval was obtained from the Institutional Review Board (IRB) of the University of Gondar. Letter of permission was obtained from the College of medicine and Health Sciences University of Gondar. Informed written consent from study participants. Confidentiality was maintained by omitting personal identifiers. This study was conducted in accordance with the Declaration of Helsinki.

\section{Acknowledgment}

The authors are indebted to the University of Gondar for funding this research. Our appreciation goes to the supervisor, data collectors, and study participants. 


\section{Author Contributions}

All the authors made substantial involvement in the conception, design, acquisition of data, or analysis and interpretation of data; took part in drafting the article or critical review of the manuscript for important intellectual content; agreed on the journal to which the article submitted; will give final approval of the version to be published; and agree to be accountable for all aspects of the work.

\section{Funding}

This research was funded by the University of Gondar.

\section{Disclosure}

The authors declare that they have no competing interests.

\section{References}

1. APA. Diagnostic and Statistical Manual of Mental Disorders. American Psychiatric Publishing; 2013.

2. Salend SJ. Teaching students not to sweat the test. Phi Delta Kappan. 2012;93(6):20-25. doi:10.1177/003172171209300605

3. Rana R, Mahmood N. The relationship between test anxiety and academic achievement. Bull Educ Res. 2010;32(2):63-74.

4. Al-Sahman LA, Al-Sahman RA, Joseph B, Javali MA. Major factors causing examination anxiety in undergraduate dental students-a questionnaire based cross-sectional study. Ann Med Health Sci Res. 2019;9(6).

5. Duraku ZH. Factors influencing test anxiety among university students. Eur J Soc Behav Sci. 2017;1(1):2325. doi:10.15405/ejsbs.206

6. Hamzah F, Mat KC, Bhagat V, Mahyiddin NS. Test anxiety and its impact on first year university students and the over view of mind and body intervention to enhance coping skills in facing exams. Res $J$ Pharm Technol. 2018;11(6):2220-2228. doi:10.5958/0974360X.2018.00411.0

7. Cassady JC. Anxiety in schools: The causes, consequences, and solutions for academic anxieties. Peter Lang; 2010.

8. Szafranski DD, Barrera TL, Norton PJ. Test anxiety inventory: 30 years later. Anxiety Stress Coping. 2012;25(6):667-677. doi:10.1080/ 10615806.2012.663490

9. Chapell MS, Blanding ZB, Silverstein ME, et al. Test anxiety and academic performance in undergraduate and graduate students. $J$ Educ Psychol. 2005;97(2):268.

10. Bembenutty H. Academic delay of gratification, self-efficacy, and time management among academically unprepared college students Psychol Rep. 2009;104(2):613-623. doi:10.2466/pr0.104.2.613-623

11. Joy JL. The altitude of test anxiety among second language learners. Lang Test Asia. 2013;3(1):10. doi:10.1186/2229-0443-3-10

12. Tsegay L, Shumet S, Damene W, Gebreegziabhier G, Ayano G. Prevalence and determinants of test anxiety among medical students in Addis Ababa Ethiopia. BMC Med Educ. 2019;19(1):423. doi:10.1186/s12909-019-1859-5

13. Kavakci O, Semiz M, Kartal A, Dikici A, Kugu N. Test anxiety prevalance and related variables in the students who are going to take the university entrance examination. J Psychiatr Neurol Sci. 2014;27:301-307.

14. Prabha V, Prakash S, Shankar RP, Itagi V. Study of examination related anxiety levels in first year medical students. Int $J$ Physiol. 2017;5(1):120-123. doi:10.5958/2320-608X.2017.00026.9
15. Miri HR, Piroozan A, Naderi N, Rezaei P. Determining the level of test anxiety and some of its contributing factors among the freshmen students. Life Sci J. 2013.

16. Tassadaq MM, Naseem M, Zafar M. Prevalence, causes and patterns of anxiety towards examinations and attitude towards coping: a study among medical students. Turk Med Stud J. 2016;3(3):79-82.

17. Saravanan C, Kingston R, Gin M. Is test anxiety a problem among medical students: a cross sectional study on outcome of test anxiety among medical students? Int J Psychol Stud. 2014;6(3):24. doi:10.5539/ijps.v6n3p24

18. Patil SG, Aithala MR. Exam anxiety: its prevalence and causative factors among Indian medical students. Natl $J$ Physiol Pharm Pharmacol. 2017;7(12):1323-1328.

19. Rajiah K, Coumaravelou S, Ying OW. Relationship of test anxiety, psychological distress and academic motivation among first year undergraduate pharmacy students. Int J Appl Psychol. 2014;4 (2):68-72.

20. Simran G, Sangeeta N, Lily W. Evaluation of examination anxiety status and its associated factors among first professional medical (MBBS) students. IJIMS. 2015;2(8):1-11.

21. Hamzah F, Mat KC, Bhagat V, Amaran S, Hassan H. Assessing test anxiety among the first year nursing students' of university Sultan Zainal Abidinb. Res J Pharm Technol. 2018;11(4):1448-1451. doi:10.5958/0974-360X.2018.00270.6

22. Dawood E, Al Ghadeer H, Mitsu R, Almutary N, Alenezi B. Relationship between test anxiety and academic achievement among undergraduate nursing students. J Educ Pract. 2016;7(2):5765 .

23. Amsalework L. The relationship between test anxiety and academic performance Addis Ababa University, Institute of Technology. 2014;1:49.

24. Sulkowski ML, Wingfield RJ, Jones D, Coulter WA. Response to intervention and interdisciplinary collaboration: joining hands to support children's healthy development. J Appl School Psychol. 2011;27 (2):118-133. doi:10.1080/15377903.2011.565264

25. Iroegbu MN. Effect of test anxiety, gender and perceived self-concept on academic performance of Nigerian students. Int J Psychol Couns. 2013;5(7):143-146.

26. Hashmat S, Hashmat M, Amanullah F, Aziz S. Factors causing exam anxiety in medical students. J Pak Med Assoc. 2008;58(4):167.

27. Canter AS, Paige LZ, Roth MD, Romero I, Carroll SA. Helping children at home and school II: handouts for families and educators. ERIC. 2004.

28. Saha K. Examination phobia and related psycho-somatic problems among the class X board examinees. Int Multidiscipl J. 2012;1 (2):232-237.

29. Masson A, Hoyois P, Cadot M, Nahama V, Petit F, Ansseau M. Girls are more successful than boys at the university. Gender group differences in models integrating motivational and aggressive components correlated with Test-Anxiety. L'Encephale. 2004;30(1):1-15. doi:10.1016/S0013-7006(04)95410-3

30. Nist P, Diehl M. PHCC test anxiety questionnaire. Retrieved Aug. 1990;20:2010.

31. Dowrick C, Casey P, Dalgard O, et al. Outcomes of Depression International Network (ODIN): background, methods and field trials. Br J Psychiatr. 1998;172(4):359-363. doi:10.1192/bjp.172.4.359

32. Rosenberg M. Society and the Adolescent Self-Image. Princeton university press; 2015.

33. Kessler RC, Barker PR, Colpe LJ, et al. Screening for serious mental illness in the general population. Arch Gen Psychiatry. 2003;60 (2):184-189. doi:10.1001/archpsyc.60.2.184

34. Suganya M, Arun B. Evaluation of exam anxiety among health science students. Int J Res Rev. 2019;6(9):359-363. 


\section{Publish your work in this journal}

Advances in Medical Education and Practice is an international, peerreviewed, open access journal that aims to present and publish research on Medical Education covering medical, dental, nursing and allied health care professional education. The journal covers undergraduate education, postgraduate training and continuing medical education including emerging trends and innovative models linking education, research, and health care services. The manuscript management system is completely online and includes a very quick and fair peer-review system. Visit http://www.dovepress.com/testimonials.php to read real quotes from published authors.

Submit your manuscript here: http://www.dovepress.com/advances-in-medical-education-and-practice-journal 